\title{
Studies on the bacteria isolated from potable water in Gambari, Southwestern, Nigeria.
}

\author{
${ }^{* 1}$ Adewoye S.O and ${ }^{2}$ Adewoye A.O \\ ${ }^{I}$ Department of Pure and Applied Biology,LadokeAkintola University of Technology, P.M.B 4000,Ogbomoso \\ ${ }^{2}$ Department of Earth Sciences,LadokeAkintola University of Technology, P.M.B 4000,Ogbomoso
}

\begin{abstract}
Bacteriological examination of twenty hand dug well water samples was carried out in Gambari, South western, Nigeria. Fifteen isolates were screened for their ability to tolerate $\mathrm{NaCl}$ and the results obtained revealed that 9 of the isolates were able to tolerate more than $140 \mathrm{mM}$, while the remaining 6 isolates also tolerated up to $128 \mathrm{mM}$. In other to establish link between $\mathrm{NaCl}$ tolerance and antibiotic resistance, antibiotic sensitivity test was carried out using Kirby-Bauer diffusion method, the tested antibiotics and their

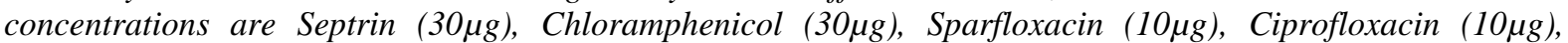

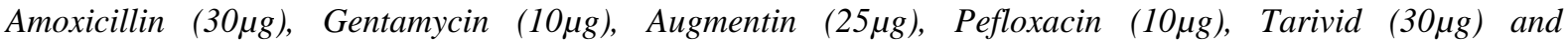
Streptomycin $(30 \mu \mathrm{g})$. The results obtained when interpreted according to the interpretative standard of National Council for Clinical Standard showed that majority of the isolates were resistant to the tested antibiotics. This study however, established link between $\mathrm{NaCl}$ tolerance and antibiotic resistance among the isolates, a trend that implicated the hand-dug wells in Gambari as sewers of pollutants.
\end{abstract}

Key Words: Antibiotics, Public Health, Resistance, Tolerance, Water

\section{Introduction}

Rural dwellers rely basically on hand dug wells for potable water as the streams usually dry up in dry season. These water resources are under threat from pollution either from human life style manifested by the level of hygiene practice in the developing nations. The neglects of rural area in most developing countries in terms of basic infrastructure, such as pipe borne water and sanitation facilities expose the villagers to a variety of health related problems such as water-borne diseases. Sequel to this, outbreaks of water-borne diseases continue to occur throughout the world but highly prevalent in developing countries (WHO, 1993; Jonesetal.,2007).The original source of any drinking water is rich inaquatic microbes, some of which could be dangerous ifthey enter the human body. Accordingly, the treatment ofwater for drinking involves stages where microbes areremoved or destroyed before the water gets into homes.After purification the water is subjected to tests by bacteriologiststo ensure the safety for human consumption.

It is well established that a large number of infectious diseases are transmitted primarily via water supplies contaminated with human and animal excreta particularly faeces (WHO, 1993). Water related diseases continue to be one of the major health problems globally. The high prevalence of diarrhea among children and infants can be traced to the use of unsafe water and unhygienic practices. Maintaining a safe drinking water remains essential to human health as transient bacteria contamination may have implication well beyond a period of acute-self limited illness.

All living organisms require a wide variety of inorganic compounds for growth, repair, maintenance and reproduction. Water is one of the most important, as well as one of the most abundant of those compounds and it is particularly, vital to living organisms (Tortoraet al., 2002). Within the cell, water is the medium for most chemical reactions. It makes up at least $5-95 \%$ of every cell and the average being between $65-75 \%$. water has been traced to be one of the ways by which humans could be infected with various kinds of diseases. Some water borne diseases include typhoid fever, cholera, bacillary dysentery and so on. In water borne infections, pathogens are usually spread by water contamination with untreated or poorly treated sewage.

Water is one of the most essential needs for the continued existence of all living organisms on earth. The day-to-day activities of all living organisms required water in whatever form. It is effectively and efficiently put into use by plants, animals, microorganisms and man. In the microbial world, no single microorganism has been discovered to be active at the extreme lack of water for the singular reason that man cannot exist without water, it is of paramount importance to monitor domestic watersupply (Sofola and Lawal, 1983).

In many developing countries, availability of water has become a critical and urgent problem and it is a matter of great concern to families and communities depending on non-public water supply system (Okonkoet al., 2008). Increase in human population exerts an enormous pressure on the provision of safe drinking water especially in developing countries (Okonkoet al., 2008). Unsafe water is a global public health threat, placing persons at risk for a host of diarrhea and other diseases as well as chemical intoxication (Hughes and Koplan, 2005). 
Unsanitary water has particularly been reported to have developing effects on young childrenin the developing world. Each year greater than 2 million persons, mostly children less than 5 years of agedie of diarrhea disease (Hughes and Koplan, 2005). For children in this age group, diarrhea disease accounted for 17\% of all death from 2000 to 2003 ranking third among causes of death, after neonatal causes and acute respiration infections (WHO, 2005).Keeping in view the importance of safe drinking water, drinking water is routinely examined to ensure safety for drinking (Jonesetal., 2007).

In water, bacteria from different origins are able to mix and resistance evolves as a consequence of promiscuous exchange and shifting of genes, genetic platform and genetic vectors (Baqueroetal., 2008). The overuse of antibiotics in human medicine and agricultural is a growing concern for public health. Overuse of antibiotics combined with inadequate wastewater treatment has led to the presence of antibiotic resistant bacteria and genes encoding antibiotics resistance in waters, river sediments. The multiple resistance of bacteria against antibiotics resulted from the fact that domestic and industrial wastes are usually released without pretreating them and so affect the underground water resources.

Exposure to antibiotic resistant bacteria can occur when the waters are used for drinking or recreation. Infection by antibiotic - resistant strains of pathogenic bacteria can have severe health implications for the sickened individual including more virulent strains and less treatment options (Barza and Travers, 2002). This study was primarily carried out to assess the bacteriological quality of hand dug well water inGambari,South Western, Nigeria.

\section{Collection of water samples}

\section{Methodology}

Twenty different water samples were collected from twenty different hand dug wells into sterile plastic bottles and labelled accordingly. The samples were collected early in the morning and transferred to the Laboratory for further analysis. The wells used were selected based on their closeness to one pollution source orthe other.

\section{Isolation and identificationof Bacteria isolates}

The isolation of bacteria was completed within 24 hours of samples collection. This was carried out by mixing $1 \mathrm{~mL}$ of the water sample with $9 \mathrm{~mL}$ of sterile distilled water and diluted serially up to $10^{-10}$. This was repeated for all the water samples. $0.2 \mathrm{ml}$ (aliquot) of the suspension was plated out of Mueller - Hinton agar. The plates were incubated $35^{\circ} \mathrm{C}$ for 24 hours. Distinct colonies growing on each plate were selected, subculture and stored on slants.All the isolates were tested for their ability to tolerate $\mathrm{NaCl}$. The following concentrations of Nacl 16, 20, 24, 28, 32, 64, 128 and 140mM were supplemented with Mueller - Hinton agar. The plates were incubated at $35^{\circ} \mathrm{C}$ for $24-72$ hours. Pure culture of all the isolates were inoculated on slant and sent for identification and biochemical characterization at Kappa technologies,Nigeria.

\section{Antibiotic Sensitivity Test}

Antibiotic susceptibility of the bacteria isolates was assayed according to the Kirby - Bauer disc diffusion method (Bauer etal., 1996). All the plates were incubated for 20 minutes before inoculation and placement of antibiotic disc to allow excess moisture to dry.After the drying, a single loop of each isolate was inoculated into sterile normal saline and compare with $0.5 \mathrm{McFarland}$ standard, the suspension was aseptically swabbed on the surface of Mueller - Hinton plates and antibiotic sensitivity disc that contains Septrin $(30 \mu \mathrm{g})$, Chloramphenicol $(30 \mu)$, Sparfloxacin $(10 \mu \mathrm{g})$, Ciprofloxacin $(10 \mu \mathrm{g})$, Amoxicillin $(30 \mu \mathrm{g})$, Augmentin $(25 \mu \mathrm{g})$, Gentamycin $(10 \mu \mathrm{g})$, Pefloxacin $(10 \mu \mathrm{g})$, Tarivid $(30 \mu \mathrm{g})$ and Streptomycin $(30 \mu \mathrm{g})$ was aseptically laid on the surface of plates. The plates were incubated at $35^{\circ} \mathrm{C}$ for 24 hours. After the incubation, zone of growth of inhibition around each disc was measured and used to classify the organisms as sensitive or resistant to an antibiotic according to the interpretive standard of the clinical and Laboratory standards institute (CLSI). 


\section{Results}

A total of 15 isolates were selected and subjected to Biochemical characterization based on their characteristics and appearance on the plates.

Table 1: Total viable count

\begin{tabular}{|l|l|l|}
\hline $\begin{array}{l}\text { Sample } \\
\text { code }\end{array}$ & $\begin{array}{l}\text { Total viable count after 24 hours of } \\
\text { incubation }\end{array}$ & Total viable count after 48 hours of incubation \\
\hline G1 & $1.4 \times 10^{5}$ & $1.7 \times 10^{5}$ \\
\hline G2 & $1.3 \times 10^{5}$ & $1.7 \times 10^{5}$ \\
\hline G3 & $1.4 \times 10^{5}$ & $1.7 \times 10^{5}$ \\
\hline G4 & $1.5 \times 10^{4}$ & $3.1 \times 10^{4}$ \\
\hline G5 & $1.7 \times 10^{3}$ & $3.5 \times 10^{3}$ \\
\hline G6 & $1.4 \times 10^{5}$ & $2.2 \times 10^{5}$ \\
\hline G7 & $1.4 \times 10^{5}$ & $1.7 \times 10^{5}$ \\
\hline G8 & $1.3 \times 10^{5}$ & $1.7 \times 10^{5}$ \\
\hline G9 & $1.4 \times 10^{5}$ & $1.7 \times 10^{5}$ \\
\hline G10 & $1.5 \times 10^{4}$ & $3.1 \times 10^{4}$ \\
\hline G11 & $1.7 \times 10^{3}$ & $3.5 \times 10^{3}$ \\
\hline G12 & $1.4 \times 10^{5}$ & $2.2 \times 10^{5}$ \\
\hline G13 & $1.4 \times 10^{5}$ & $1.9 \times 10^{5}$ \\
\hline G14 & $1.6 \times 10^{5}$ & $3.4 \times 10^{5}$ \\
\hline G15 & $1.4 \times 10^{5}$ & $1.7 \times 10^{5}$ \\
\hline G16 & $1.5 \times 10^{4}$ & $3.1 \times 10^{4}$ \\
\hline G17 & $1.7 \times 10^{3}$ & $3.5 \times 10^{3}$ \\
\hline G18 & $1.4 \times 10^{5}$ & $2.6 \times 10^{5}$ \\
\hline G19 & $1.7 \times 10^{5}$ & $3.0 \times 10^{5}$ \\
\hline G20 & $1.3 \times 10^{5}$ & $1.7 \times 10^{5}$ \\
\hline & & \\
\hline
\end{tabular}

Table2: Probable identity of the isolates

\begin{tabular}{|l|l|}
\hline LAB CODE & PROBABLE IDENTITY \\
\hline H1 & Staphylococcusaerus \\
\hline H2 & Escherichiacoli \\
\hline H3 & Klebsiellaedwardsii \\
\hline H4 & Klebsiellaoxytoca \\
\hline H5 & Shigellaalkalescens \\
\hline H6 & Pseudomonasaeruginosa \\
\hline H7 & Bacillus cereus \\
\hline H8 & Escherichiacoli \\
\hline H9 & Staphylococcussp \\
\hline H10 & Streptococcusfaecium \\
\hline H11 & Streptococcusfaecieum \\
\hline H12 & Escherichiacoli \\
\hline H13 & Staphylococcusaereus \\
\hline H14 & Shigellaalkalescens \\
\hline H15 & Klebsiellaoxytoca \\
\hline
\end{tabular}


Studies on the bacteria isolated from potable water in Gambari, Southwestern, Nigeria.

TABLE 3: Minimum Inhibitory Concentration of $\mathrm{NaCl}$

\begin{tabular}{|c|c|c|c|c|c|c|c|}
\hline \multirow{2}{*}{ ANTIBIOTICS } & \multicolumn{7}{|c|}{ ISOLATES } \\
\hline & $\begin{array}{l}\text { Staphylococcus } \\
\text { spp. } \\
\mathrm{n}=3\end{array}$ & $\begin{array}{l}\text { E. coli } \\
\mathrm{n}=2\end{array}$ & $\begin{array}{l}\text { Shigella spp. } \\
\mathrm{n}=2\end{array}$ & $\begin{array}{l}\text { Klebsiella spp. } \\
\mathrm{n}=3\end{array}$ & $\begin{array}{l}\text { Streptococcus } \\
\text { spp. } \\
\mathrm{n}=2\end{array}$ & $\begin{array}{l}\text { Bacillus } \\
\text { spp. } \\
\mathrm{n}=1\end{array}$ & $\begin{array}{l}\text { Pseudomonasspp. } \\
\mathrm{n}=2\end{array}$ \\
\hline Septrin $(30 \mu \mathrm{g})$ & $\mathrm{R}$ & $\mathrm{R}$ & $\mathrm{R}$ & $\mathrm{R}$ & $\mathrm{R}$ & $\mathrm{R}$ & $\mathrm{R}$ \\
\hline $\begin{array}{l}\text { Chlorophenicol } \\
(30 \mu \mathrm{g})\end{array}$ & $\mathrm{R}$ & $\mathrm{R}$ & I & $\mathrm{R}$ & $\mathrm{R}$ & $\mathrm{R}$ & $\mathrm{R}$ \\
\hline Sparfloxacin $(10 \mu \mathrm{g})$ & $\mathrm{R}$ & $\mathrm{R}$ & $\mathrm{R}$ & $\mathrm{R}$ & $\mathrm{R}$ & $\mathrm{R}$ & $\mathrm{R}$ \\
\hline Ciprofloxacin $(10 \mu \mathrm{g})$ & $\mathrm{S}$ & $\mathrm{R}$ & $\mathrm{R}$ & $\mathrm{S}$ & $\mathrm{S}$ & $\mathrm{R}$ & $\mathrm{R}$ \\
\hline Amoxicillin $(30 \mu \mathrm{g})$ & $\mathrm{R}$ & $\mathrm{R}$ & I & I & $\mathrm{R}$ & I & I \\
\hline Augmentin $(25 \mu \mathrm{g})$ & $\mathrm{R}$ & $\mathrm{R}$ & $\mathrm{R}$ & $\mathrm{S}$ & $\mathrm{R}$ & $\mathrm{R}$ & $\mathrm{R}$ \\
\hline Gentamycin $(10 \mu \mathrm{g})$ & $\mathrm{R}$ & $\mathrm{R}$ & $\mathrm{R}$ & $\mathrm{R}$ & $\mathrm{R}$ & $\mathrm{R}$ & $\mathrm{R}$ \\
\hline Pefloxacin $(10 \mu \mathrm{g})$ & $\mathrm{R}$ & $\mathrm{R}$ & $\mathrm{R}$ & $S$ & $\mathrm{R}$ & $\mathrm{R}$ & $\mathrm{R}$ \\
\hline Tarivid $(30 \mu \mathrm{g})$ & $\mathrm{S}$ & $\mathrm{R}$ & $\mathrm{R}$ & $S$ & $\mathrm{~S}$ & $\mathrm{~S}$ & $\mathrm{R}$ \\
\hline Streptomycin $(30 \mu \mathrm{g})$ & $\mathrm{S}$ & $\mathrm{R}$ & $\mathrm{R}$ & $\mathrm{S}$ & $\mathrm{S}$ & $\mathrm{S}$ & $\mathrm{R}$ \\
\hline
\end{tabular}

Tested concentrations : $16,20,24,28,32,64,128$ and $140 \mathrm{mM}$

TABLE 4: Result of Antibiotics sensitivity test

\begin{tabular}{|l|l|l|}
\hline LABORATORY CODE & ORGANISMS & CONCENTRATION $(\mathrm{mM})$ \\
\hline H1 & S.aerus & $\geq 140$ \\
\hline H2 & E.coli & 128 \\
\hline H3 & Kl.edwardsii & 128 \\
\hline H4 & Kl.oxytoca & $\geq 140$ \\
\hline H5 & S.alkalescens & $\geq 140$ \\
\hline H6 & P.aeruginosa & $\geq 140$ \\
\hline H7 & B.cereus & 128 \\
\hline H8 & E.coli & 128 \\
\hline H9 & Staph.sp & $\geq 140$ \\
\hline H10 & S.faecium & 128 \\
\hline H11 & S.faceum & $\geq 140$ \\
\hline H12 & E.coli & 128 \\
\hline H13 & S.aereus & $\geq 140$ \\
\hline H14 & S.alkalesceus & $\geq 140$ \\
\hline H15 & Kl.oxytoca & $\geq 140$ \\
\hline
\end{tabular}

R:Resistance,S:Sensitive,I: Intermidiate

\section{Discussion}

The results of total viable count and characterization of bacteria isolates are presented in table 1 and 2 respectively. From the results of total viable count it was clearly apparent that the water samples were highly polluted this is because the bacteria contamination level is determined high in all the water samples. Similar observations have been reported by Okonko et al.,(2008).Ln this study Out of 15 isolates that were sent for biochemical characterization three (3), two (2), three (3), two (2), one (1) and two (2) were identified to be Staphylococcus spp., E. coli, Shigella spp., Klebsiella spp., Streptococcus spp., Bacillus spp. and Pseudomonas spp respectively(table 2) .

The results of halotolerant assay and antibiotic sensitivity test are presented in tables 3 and 4 , the results obtained from halotolerantassay revealed that nine (9) out of fifteen (15) isolates were able to tolerate more than $140 \mathrm{mM}$, while the remaining 6 isolates also tolerate up to $128 \mathrm{mM}$, this showed that all the isolates have innate ability to cope with the effects of Nacl.From table 4,it was observed that all the isolates showed multiple antibiotic resistance against all the tested antibiotics.

The presence of antibiotic resistant bacteria in water sources throughout the world has been documented (Kelch and Lee, 1978; French et al., 1987; Ogan and Nwiika, 1993; Young, 1993).The use of antibiotics in medicine and veterinary practice, has aroused some concern about the incidence and spread of antibiotic resistance among bacteria populations. As a result of the usage of antibiotics in medical or veterinary 
Studies on the bacteria isolated from potable water in Gambari, Southwestern, Nigeria.

practice, selected for resistant bacteria, these bacteria have inevitably entered the naturally environment. This is particularly true when transfer occurs in environments such as hospitals where the human population is at risk (Jones etal., 1986).

Efforts are being taken by all technological advancements including antibiotic usage to control transmission of water-borne diseases, but multi-drug resistance by some organisms such as Escherichia coli, warrants the beginning of steps to prevent public health hazards(Tambekaret al., 2006; Pandey and Musrat, 1993). The use, misuse and under-use of antibiotics are responsible for resistance development to bacterial antimicrobials worldwide. Antibiotic resistance has been reported in Acinetobacter, Alkaligenes, Citrobacter, Enterobacter, Pseudomonas, Serratiasppisolated from river (Pavenet al., 1997). Antibiotics used in poultry or agriculture practice to prevent disease can contaminate surface and underground water (Ash, 2002) from where they can be transported to humans in drinking water thereby adding to resistance problems (Niemietal., 1997).

Lateef (2004) reported that in developing countries, drugs are available to the public and thus people may practice self - administration of antibiotics and further increase the prevalence of drug - resistant strains. There have been many surveys of the occurrence of antibiotic resistant E. coli in animals (Jackson, 1981; Matyaretal., 2004). Chong etal., (1990) found that 204 of 400 faecal samples from human sources containing $E$. coli were resistant to one or more antibiotics at a rate of $83 \%$.

The relatively high level of resistance to antimicrobial agents recorded in this study is a reflection of misuse or abuse of these agents in the environment. Multiple drug resistance are an extremely serious public health problem and it has been found associated with the outbreak of major epidemic throughout the world. Thus, the multiple - drug resistance shown by these pathogens are worrisome (Lateef, 2004). Encountering multiple antibiotic resistant $E$. coli in this study is therefore not a surprise but worrisome because of its pathogenicity. Therefore, the occurrence of multiple antibiotic resistant pathogenic bacteria encountered in this study represents a well-known phenomenon that carries a negative impact for public health, an observation that it is in consonance with the reports of Torogoluetal., (2005).

In this study the percentage of antibiotic resistant bacteria recorded for all the tested antibiotic is dreadful because all the isolates were resistant to almost all the antibiotics that are commonly use in the medicine and agriculture for prevention and treatment of infections. The reason for this could be as a result of the exposure of the isolates to the toxic effects of cyanide that is present in the cassava effluent that polluted the hand dug well water used in this study, because the major occupation in the sampling station is cassava processing. Similarly, apart from the exposure of the isolates to the toxic effect of cyanide, majority of the selected hand dug wells were very close to the major roads where they receive automobile exhausts from cars, lorries and trucks because the settlement is located on the highway, this could also cause resistant because of the toxic effect of hydrocarbons.

Most of the tested antibiotics have been widely used for therapeutic purposes against bacterial infection as well as growth promoters in agricultural and aquaculture, therefore the occurrence of antibiotic resistant bacteria in samples collected from hand dug well very close to poultry is in consonance with the reports of Kruse and Sorum (1994),Khachatourians (1998); Aarestrup and Muller (1999). Similarly Multidrug resistance phenotypes of $E$. coli isolated from water sources have been reported worldwide (Salvadorietal., 2004; Raintake and Tewari, 2007; Ozgumaset al., 2007; Ram etal., 2008; Toola and Dincer, 2008). This study clearly established a link between antibiotic resistance and Nacl tolerance among the bacteria isolates, a trend that implicated the hand-dug wells in Gambari as sewers of pollutants.

\section{Conclusion}

The results obtained in this studyshowed that the hand dug well water in Gambari is highly polluted and Government has to come to the aid of the resident in other to save them from the health risk of drinking contaminated water and particularly for the realization of Millennium Development Goal that promised clean and safe water for at least $50 \%$ of the total world population before the year 2015 .

\section{References}

[1]. Aarestrup A, MØller F 1999. Association between the consumption of antimicrobial agents in animal husbandry and the occurrence of resistant bacteria among food animals. Int. J. Antimicrobial Agents, 12: $279-285$.

[2]. Baquero F. Martinez J.L., Canton R. 2008. Antibiotic and antibiotic resistance in water environments. Curr. Opin. Biotechnol. 19: $260-265$.

[3]. Barza M, Traverts K 2002. Excess infections due to antimicrobial resistance: the "Attributable fraction", In: The need to improve antimicrobial use in agriculture: Ecological and Human Health Consequences. Clin. Infect. Dis., 34: 126 - 130.

[4]. Bauer A.W ,Kirby W.M.M, SherrisJ.C,Turck M 1966.Antibiotic susceptibility testing by a standardized single disk method.AM. J. Clin.Pathol. 45: $493-496$.

[5]. Cheong Y.M., Jegathesan M., Ansary A., Othman M. 1990. Comparison of methods in the detection of enterotoxigenicEscherichia coli in a Malaysian laboratory. Med. J. Malaysia, 45: $42-48$

[6]. French G.L, Luig J., Chow K.W., Mark K.K. 1987. Occurrence of multiple antibiotic resistance and R - Plasmid in gram - negative bacteria isolated from fecally contaminated freshwater streams. Epi Infect., 98: 285 - 299.

[7]. Hughes JM, Koplan JP 2005. Saving lives through global safe water. J. Emerging Infect. Dis. 11(10): 1636- 
[8]. Jackson G. 1981. A survey of antibiotic resistance of Escherichia coli isolated from farm animals in Great Britain from 1971 to 1977. Vet. Rec., 108: 325 - 328 .

[9]. Jones J.G., Gardener S., Simon B.M., Pickup R.W. 1986. Antibiotic resistant bacteria in Windermere and two remote upland towns in the English Lake District. J. Appl. Environ. Microbial.,36: 450 - 456.

[10]. Kelch W.J. Lee J.S. 1978. Antibiotic resistance patterns of gram negative bacteria isolated from environmental sources Appl. Environ. Microbial. 36. 450 - 456.

[11]. KhachaotouriansG.1998.Agricultural use of antibiotics and the evolution and transfer of antibiotic resistant bacteria.Can.Med.Assoc. J.,159:1129-1136.

[12]. Kruse H, Sorum H1994.Tranfer of multiple drug resistance plasmids between bacteria of diverse origins in natural microenvironments. Appl. Environ. Microbial,60:4015-4021.

[13]. Lateef A. 2004. The microbiology of a pharmaceutical effluent and its public health implications. World J. microbial Biotechnol.,20: $167-171$.

[14]. Matyar F., Dincer S., Kaya A., Colak Ó. 2004. Prevalence and resistance to antibiotic in Gram - negative bacteria isolated from retail Fish in Turkey. Ann Microbiol.,54 (2): 23 - 32.

[15]. Niemi R.M., Niemela S.I., Lahti K., Niemi J.S. 1997. Coliforms and E. coli in finish surface waters. In: kay D., Eds. Coliforms and E. coli problem or solution? The Royal society of chemistry, Cambridge, UK. P. 112 - 199.

[16]. Ogan M.T, Nwiika D.E. 1993. Studies on the ecology of aquatic bacteria on the lower Niger Delta: multiple antibiotic resistance among the standard plate count organisms. J. Appl. Bacteriol.,74: 595 - 602.

[17]. Okonko IO, Adejoye OD, Ogunusi TA, Fajobi EA, Shittu OB 2008. Microbiological and physiochemical analysis of different water samples used for domestic purposes in Abeokuta and Ojota, Lagos State, Nigeria. Afr. J. Biotechnol. 7(3): 617-621.

[18]. Ozgumus O.B., Celik - Environ. Monitor. Assess - 130:215 - 220.Sevim E., Alpay - Karaoglu S., Sandalli C., Sevim A. 2007. Molecular characterization of antibiotic resistant E. coli strains isolated from cattle and pigs by the use of PCR and pulsed - field gel electrophoresis methods. Vet. Med. Czech, 47: $149-158$.

[19]. Ram S. Vajpayee P., Tripathi U, Singh R.L., Seth p.K., Shanker R. 2008. Determination of antimicrobial resistance and virulence gene signature in surface water isolates of E. coliJ. Appl. Microb. 39: 494 - 497.

[20]. Ramteke P., tewari S.2007. Serogroups of Escherichia coli from Drinking water.

[21]. Salvadori M., Coleman B.L., louie M., McEwen S., McGeer A.2004. Consumption of Antimicrobial - Resistant Escherichia coli contaminated well water: Human Health impact. PSI clinical research.

[22]. Sofola TO, Lawal M 1983. Bacteriological analysis of water samplesfrom main taps and domestic water storage tanks in metropolitan

[23]. TorogluS., Dincer S., and H. Korkinaz2005. Antibiotic resistance in gram negative bacteria isolated from AKSU river in Turkey. Ann. Microbial.,55: $221-223$.

[24]. Toróolu S., Dincer S. 2008. Elimination and Conjugal transfer of their resistance in isolated Gram Negative bacteria from AKSV River (Kahramanra - Turkey). Adv. Environ. Biol. 2: $124-131$.

[25]. Tortora JG, Funke RB, Case LC 2002. Microbiology An introduction. Media update of 7 Edn.including bibliography and index publisher. Daryl Fox; pp: 258-260.

[26]. World Health Organization. 2005. The WHO report 2005- makes every mother and child count Geneva: The organization 2005.

[27]. Young H.K 1993. Antimicrobial resistance spread in aquatic environments. J. Antimicrobial. Chemother. $31: 627$ - 632. 